\title{
Preparation of chitosan nanoparticles and characterization studies
}

\section{Kitozan nanopartikülllerin hazırlanması ve karakterizasyon çalışmaları}

\section{Murat Doğan}

Sivas Cumhuriyet University, Faculty of Pharmacy, Department of Pharmaceutical Biotechnology, Sivas, Turkey

Corresponding author: Murat Doğan, PhD, Sivas Cumhuriyet University, Faculty of Pharmacy, Department of Pharmaceutical Biotechnology, Sivas, Turkey

E-mail: mdogan@cumhuriyet.edu.tr

Received/Accepted: September 15, 2020 / October 26, 2020

Conflict of interest: There is not a conflict of interest.

\section{SUMMARY}

Objective: The aim of this study was to prepare different nanoparticles using chitosan and tripolyphosphate and to perform characterization studies of nanoparticles. In addition, FTIR spectrum measurements were aimed to determine specific chemical groups and bonds in the structures of nanoparticles and materials.

Method: In this study, different nanoparticles were prepared and their zeta potential, particle size and polydispersity index were measured. Moreover, specific chemical groups of nanoparticles and materials used in nanoparticles were determined by FTIR spectrum studies. Morphological properties of nanoparticles were evaluated using scanning electron microscopy.

Results: According to the zeta potential measurement results, A3 (18.66 \pm $0.22)$ and $\mathrm{A} 2(14.32 \pm 0.14)$ formulations showed the highest and the lowest zeta potential value, respectively. It was also observed that the A3 (284.22 \pm 1.60 ) formulation had the lowest particle size. According to FTIR absorption spectrum results, a wide aliphatic $\mathrm{O}-\mathrm{H}$ tension band of chitosan was observed between $1500 \mathrm{~cm}^{-1}-1100 \mathrm{~cm}^{-1}$.

Conclusions: According to the results, it could be said that chitosan nanoparticles have desired particle size, charge and morphological properties in terms of application. In FTIR spectrum results, bands showing specific chemical groups of chitosan, tripolyphosphate and $\mathrm{A} 3$ formulation were obtained.

Keywords: Chitosan, nanoparticle, drug delivery.
Murat Doğan

ORCID IDs of the authors: M.D. 0000-0003-2794-0177

\section{ÖZET}

Amaç: Bu çalışmanın amacı, kitozan ve tripolifosfat kullanarak farklı nanopartikülleri hazırlamak ve nanopartiküllerin karakterizasyon çalışmalarını yapmaktır. Ayrıca nanopartiküllerin ve materyallerin yapılarında bulunan özgün kimyasal grupları ve bağları belirlemek için FTIR spektrum ölçümleri yapılması amaçlanmıştır.

Yöntem: Çalışmada farklı nanopartiküller hazırlanmış ve zeta potansiyelleri, boyutları ve poli dispers indeksleri ölçülmüştür. Ayrıca FTIR spektrum çalışmasıyla nanopartiküllerde kullanılan maddelerin ve nanopartikülün özgün kimyasal grupları belirlenmiştir. Taramalı elektron mikroskopu ile nanopartiküllerin morfolojik özellikleri değerlendirilmiştir.

Bulgular: Zeta potansiyel ölçüm sonuçlarına göre A3 (18.66 \pm 0.22$)$ ve A2 (14.32 \pm 0.14$)$ formülasyonları sırasıyla en yüksek ve en düşük zeta potansiyel değeri göstermiştir. Ayrıca, A3 (284.22 11.60) formülasyonunun en düşük partikül 
boyutuna sahip olduğu gözlenmiștir. FTIR absobsiyon spektrum sonuçlarına göre kitozana ait geniș bir alifatik O-H gerilim band $1500 \mathrm{~cm}^{-1}-1100 \mathrm{~cm}^{-1}$ aralığında gözlenmiştir.

Sonuç: Sonuçlara göre, kitozan nanopartiküllerin uygulama açısından istenen boyut, partikül yükü ve morfolojik özelliklere sahip olduğu söylenebilir. FTIR spektrum sonuçlarında kitozan, tripolifosfat ve A3 formülasyonunun özgün kimyasal gruplarını gösteren bantlar elde edilmiştir.

Anahtar sözcükler: Kitozan, nanopartikül, ilaç taşınması.

\section{INTRODUCTION}

Chitosan (CS) is a biopolymer that is used widely in pharmaceutical and biomedical fields due to its unique properties such as safety, biocompatible, and biodegradable. CS is a linear copolymer formed by the combination of $\mathrm{N}$-acetyl glucosamine and glucosamine units ${ }^{1}$. CS shows cationic properties due to the amine groups in its structure, and the positive charges carried by CS interact strongly with many minerals and cells that carry negative charges such as fats, proteins and tumor cells in the body. In addition, CS enables the encapsulation of drugs by forming complexes with electrostatic interactions ${ }^{2,3}$. CS has a hydrophobic structure and is insoluble in water and many organic solvents. However, it dissolves in dilute acid solution. The unique properties of CS such as its polycationic property, biocompatible and inert structure, and easily biodegradable enable it to be used in preparation of nanoparticles (NP) and microparticles ${ }^{4}$. CS NPs are prepared using methods such as simple-complex coacervation, solvent evaporation, suspension polymerization, ionotropic gelation, and spray drying. Ionic gelation is a technique commonly used to prepare NPs. This process is based on the ionic interaction between positively charged amino groups of CS and negatively charged groups of a polyanion such as tripolyphosphate (TPP) ${ }^{6}$. TPP is the most widely used crosslinker in preparing CS NPs because of its safety and unique properties. The particle properties such as the size and zeta potential play a crucial role in evaluating its biological behavior ${ }^{5,7}$. These properties affect the cellular uptake, protein adsorption, and their distribution throughout the body. CS NPs are widely used in different applications, ranging from drug delivery, tissue engineering, and wound dressing to bio-sensing and enzymes immobilization ${ }^{8}$. Nanoparticles derived drug delivery systems are the ability to deliver a drug selectively to a specific site, less frequent dosing and absorption that is more consistent with the site and mechanism of action. These desired and crucial properties of nanoparticle derived drugs provides widely using area in medicine $e^{7,8}$. There are many polymers used in the preparation of nanoparticular systems, but nanoparticles prepared with chitosan have superior properties compared to others. Chitosan nanoparticles have the advantage of controlled drug release, which improves drug stability and solubility, enhances efficacy, and reduces toxicity. These nanoparticles are capable of passing through biological barriers such as the blood-brain barrier $^{5,8}$.

The aim of this work was the preparation and characterization of CS NPs as drug delivery systems using the ionotropic gelation method. Moreover, NPs were optimized by monitoring particle shape and morphology, and evaluating particle size, polydispersity, surface charge, and infrared spectrum results.

\section{MATERIAL AND METHODS}

Medium molecular weight CS and TPP were purchased from Sigma-Aldrich (USA). All materials used in these studies were in analytical grade.

\section{Preparation of chitosan nanoparticles}

Ionic gelation method was used in the preparation of CS NPs. With this technique, the effect of CS/crosslinker ratio on CS NP was investigated ${ }^{2,4}$. The concentration of CS in the formulations was determined as $0.25 \%$ and $0.50 \%$. It was decided to prepare TPP solutions at $0.25 \%$ and $0.50 \%$ concentrations to examine the effect of TPP used as crosslinker on CS NP size. The formulations and their ratio and amounts are given in Table 1. $0.0625 \mathrm{~g}$ of CS was weighed on a precision scale. Glacial acetic acid solution ( $25 \mathrm{ml}, 0.25 \%)$ was added to the beaker containing CS. A magnet of suitable size was inserted into the beaker and its mouth was closed with parafilm and dissolved in a magnetic stirrer. In addition, $0.0625 \mathrm{~g}$ of TPP was weighed on a precision scale, completed with $25 \mathrm{ml}$ of sterile bidistilled water, and dissolved by heating in a magnetic stirrer $\left(70-80{ }^{\circ} \mathrm{C}\right)$. Then, dissolved TPP was dropped with a dropper at a predetermined height and time $(30 \mathrm{~min})$ to $\mathrm{CS}$. After this process, a cloudy colored CS-TPP mixture with pellets at the bottom was observed. The beaker was sealed with parafilm and stirred in a magnetic stirrer at $900 \mathrm{rpm}$ for two hours. The cloudy colored mixture was transferred to the centrifuge tube and centrifuged for 15 minutes 
$\left(12,000 \mathrm{rpm}, 4{ }^{\circ} \mathrm{C}\right)$. After centrifugation, the pellet at the bottom of the tube and the clear supernatant at the top of the tube were observed. Then, the supernatant was carefully discarded and sterile bidistilled water was added to the pellet and suspended by vortexing. Centrifuge and vortex processes were repeated three times in order to eliminate possible impurities in the NPs. After these procedures, the centrifuge tube containing the pellet was kept at $-20{ }^{\circ} \mathrm{C}$ overnight. For lyophilization process, CS NP in the centrifuge tube was taken into a suitable petri dish, its mouth was closed with parafilm, and holes were made on the parafilm with a pin. In the lyophilization process, the NPs should be followed carefully in order to dry them as desired. Lyophilized CS NPs were pulverized with a sterile baguette and stored in ependorfh. This process was performed sequentially in each NP formulation.

Table 1: Chitosan nanoparticles and parameters.

\begin{tabular}{|c|c|c|}
\hline Formulations & Chitosan (\% w/v) & TPP (\% w/v) \\
\hline A1 & 0.25 & 0.25 \\
\hline $\mathbf{A 2}$ & 0.25 & 0.50 \\
\hline $\mathbf{A 3}$ & 0.50 & 0.25 \\
\hline $\mathbf{A 4}$ & 0.50 & 0.50 \\
\hline
\end{tabular}

\section{Measurement of the particle size and zeta potential of nanoparticles}

Particle size, zeta potential, and polydisperse index of NP are crucial in drug delivery, targeting, and cellular uptake of $\mathrm{NP}^{5,6}$. Cellular uptake of the NP takes place in two steps respectively. The first step is to bind to the cell membrane via cell surface receptors and the second step is to enter the cell ${ }^{8}$. Particle size and zeta potential of NPs were measured with Malvern Zetasizer. Half an hour before the measurement, Malvern Zetasizer should be turned on and calibrated. After determining the features required for measurement of the device, measurement is started. Before the measurement, the cuvette in which the measurement will be made was cleaned with ethanol and bidistilled water. A small amount of NP was taken into an eppendorf with a sterile syringe tip. The NP in eppendorf was made up to $1 \mathrm{ml}$ volume with phosphate buffer saline (PBS). The sample to be measured should be sufficiently diluted and should not have a blurry appearance. Just before the measurement, our sample in the eppendorf is taken into the cuvette by brief vortexing. The particle size measurements of the NPs were performed first in order to prevent possible aggregation. Then, zeta potentials of NPs were measured.

\section{Scanning electron microscopy}

The lyophilized NP was placed on metal grids, coated with gold to $8 \mathrm{~nm}$ in thickness using SCD 005 Sputter coater (Baltec, Liechtenstein) under a high vacuum. The surface morphology of NPs was investigated by scanning electron microscopy (SEM; Carl Zeis-Evo 40, Germany).

\section{Infrared absorption spectroscopy (FTIR) study}

Fourier Transform Infrared Spectroscopy (FTIR) was used to indicate specific chemical groups in the $\mathrm{NP}$ and materials ${ }^{9}$. The infrared spectrum studies of NP were performed (Perkin Elmer 1600 FT-IR, England). Infrared spectrum measurements of CS and TPP were performed with the same method.

\section{RESULTS and DISCUSSION}

\section{Assessment of particle size and zeta potential results}

The particle size of the CS NPs was obtained between $284.22 \pm 1.60$ and $420.36 \pm 2.84 \mathrm{~nm}$ (Table 2). A2 formulation with low concentration of CS $(0.25 \%)$ and high concentration of TPP $(0.50 \%)$ had highest particle size. In addition, A3 formulation containing high concentration of CS $(0.50 \%)$ and low concentration of TPP $(0.25 \%)$ had the lowest particle size. The zeta potential of the NPs was between $14.32 \pm 0.14$ and $18.66 \pm 0.22$ $\mathrm{mV}$. A2 formulation with low concentration of CS $(0.25 \%)$ and high concentration of TPP $(0.50 \%)$ had lowest zeta potential value. In addition, A3 formulation containing high concentration of CS $(0.50 \%)$ and low concentration of TPP $(0.25 \%)$ had the highest zeta potential value. According to the results, it was observed that NPs charge decreased and size increased depending on the TPP 
concentration used as crosslinker. The PDI of the NPs was in the range between $0.18-0.27$ and no significant difference was observed between the
NP formulations. These results showed that the NPs were homogeneous and the method used was suitable.

Table 2: Chitosan nanoparticles prepared under different conditions, particle size (nm), zeta potential (mV), and polydispersity index.

\begin{tabular}{|l|l|l|l|}
\hline Formulations & $\begin{array}{l}\text { Particle size } \\
(\mathbf{n m}) \pm \text { SD }\end{array}$ & $\begin{array}{l}\text { Zeta Potential } \\
(\mathbf{m V}) \pm \text { SD }\end{array}$ & PDI* \\
\hline A1 & $326.44 \pm 2.40$ & $16.38 \pm 0.24$ & 0.27 \\
\hline A2 & $420.36 \pm 2.84$ & $14.32 \pm 0.14$ & 0.25 \\
\hline A3 & $284.22 \pm 1.60$ & $18.66 \pm 0.22$ & 0.21 \\
\hline A4 & $350.16 \pm 1.82$ & $17.74 \pm 0.28$ & 0.18 \\
\hline
\end{tabular}

* Polydispersity index: PDI

The size and morphological properties of the CS NPs were characterized by SEM. CS NPs were found to have a smooth surface morphology
(Figure 1 and 2). In addition, SEM images of the NPs were compatible with size measurements using Zetasizer.

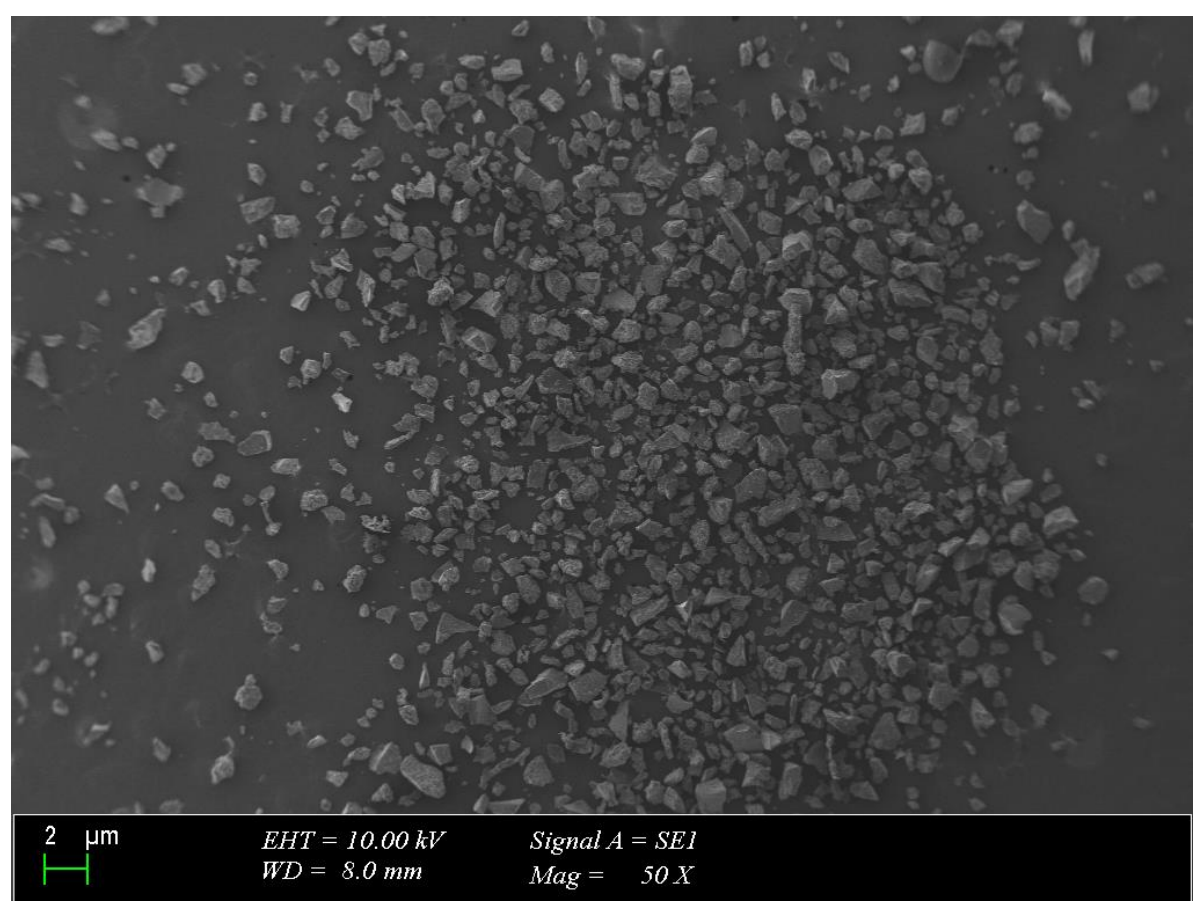

Figure 1: SEM images of CS NP (A3) 


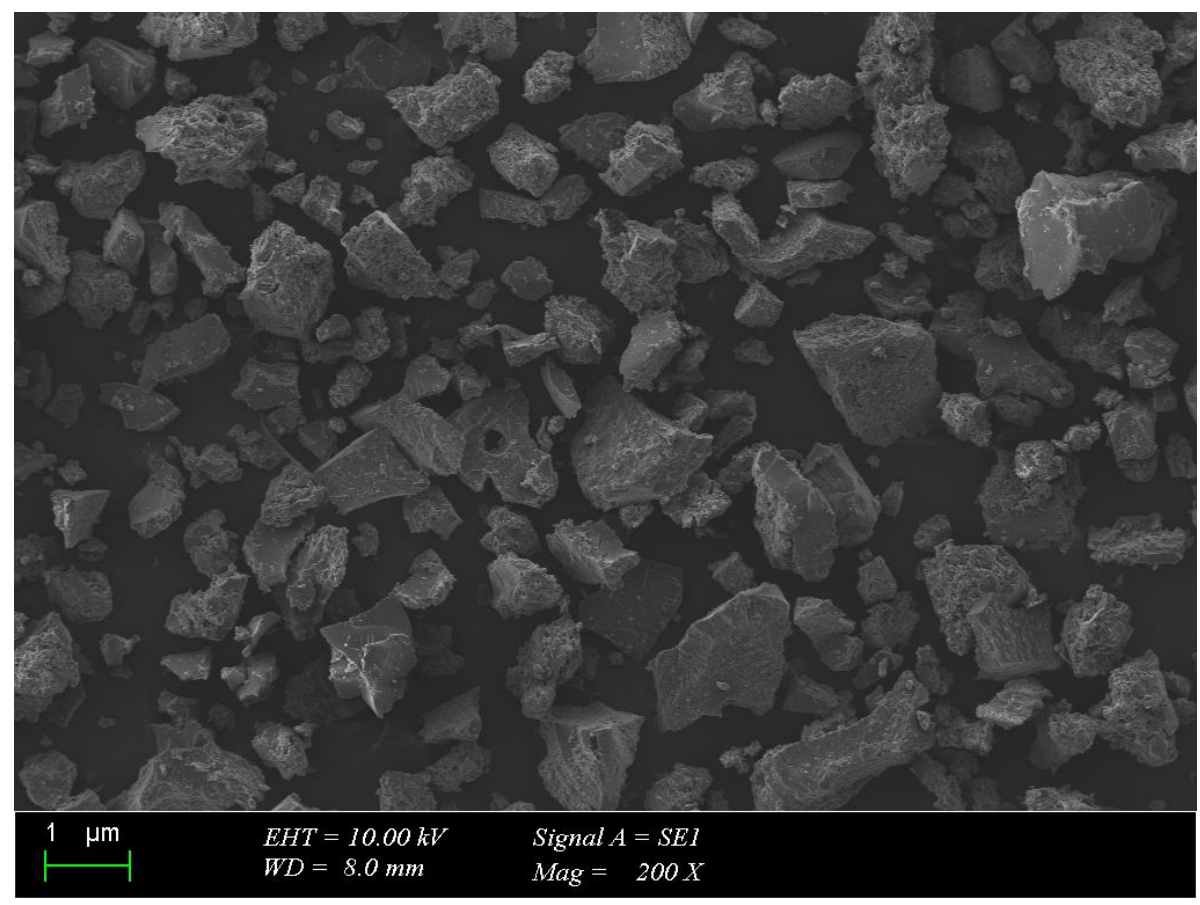

Figure 2: SEM images of CS NP (A4)

\section{Evaluation of FTIR spectrum results}

The results of IR absorption spectroscopy of CS and TPP were shown in Figure 3 and Figure 4, respectively. FTIR spectrum results were similar to the studies of Vino et $a l^{9}$. The characteristic functional groups such as amine $-\mathrm{N}-\mathrm{H}$ symmetrical stretching $\left(3358 \mathrm{~cm}^{-1}-3288 \mathrm{~cm}^{-1}\right)$ and $\mathrm{O}-\mathrm{H}$ asymmetric stretching $\left(3099 \mathrm{~cm}^{-1}\right)$ showed the CS.
The presence of $\mathrm{N}$-acetyl groups was shown by the bands at around $1645 \mathrm{~cm}^{-1}(\mathrm{C}=\mathrm{O}$ stretching of amide I). $1558 \mathrm{~cm}^{-1}$ second amide bond corresponded to $\mathrm{N}-\mathrm{H}$ bending of amide II. The $\mathrm{CH}_{3}$ symmetrical stretching and $\mathrm{CH}_{2}$ bending were confirmed by the presence of bands at $1374 \mathrm{~cm}^{-1}$ and $1411 \mathrm{~cm}^{-1}$, respectively. A similar absorption band was obtained to Song et al. study ${ }^{10}$.

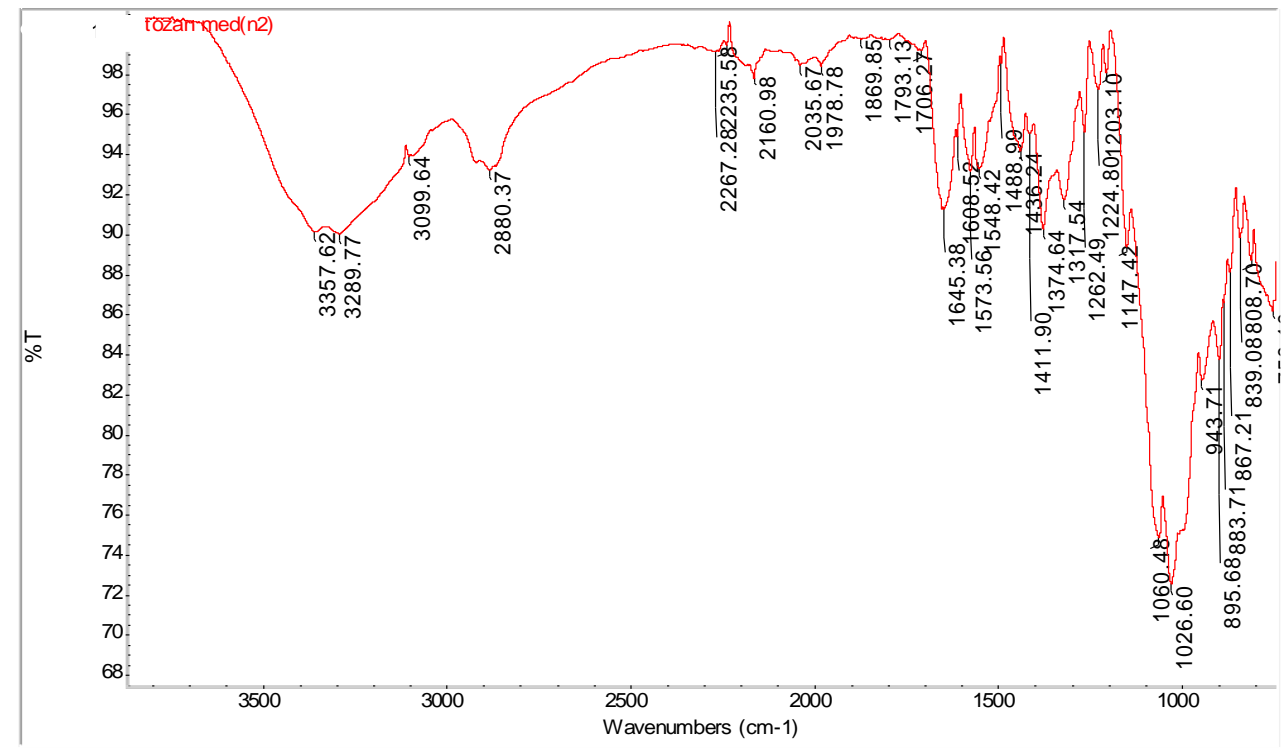

Figure 3: FTIR spectrum of CS (medium molecular weight) with the characteristic signs. 


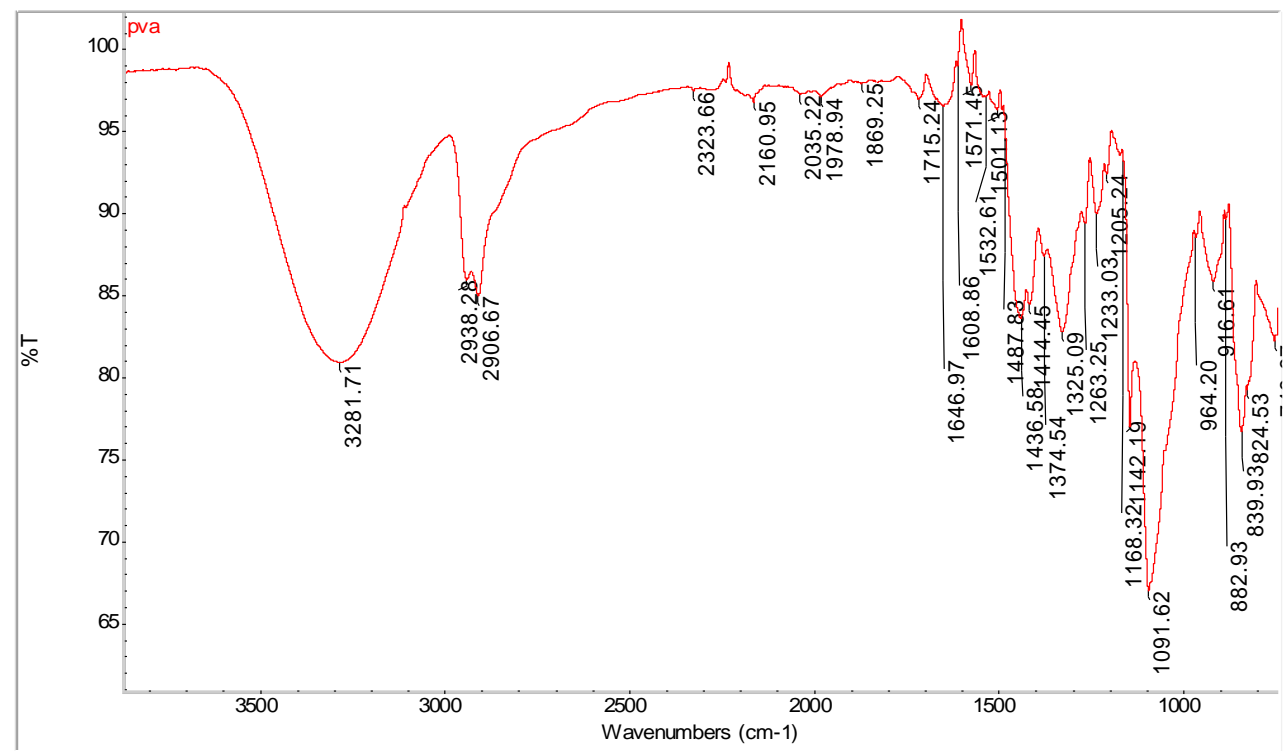

Figure 4: FTIR spectrum of TPP with the characteristic signs.

The results of IR absorption spectroscopy of CS NP were shown in Figure 5. The presence of the $\mathrm{P}=\mathrm{O}$ stretching peak at $1204 \mathrm{~cm}^{-1}$ and $\mathrm{P}-\mathrm{O}$ bending at $883 \mathrm{~cm}^{-1}$ of the TPP were observed in the sample of NPs. In addition, -NH2 bending vibration of CS NPs was obtained at $1545 \mathrm{~cm}^{-1}$. Similar results were obtained to the studies of Melo-Silveira et $\mathrm{al}^{11}$.

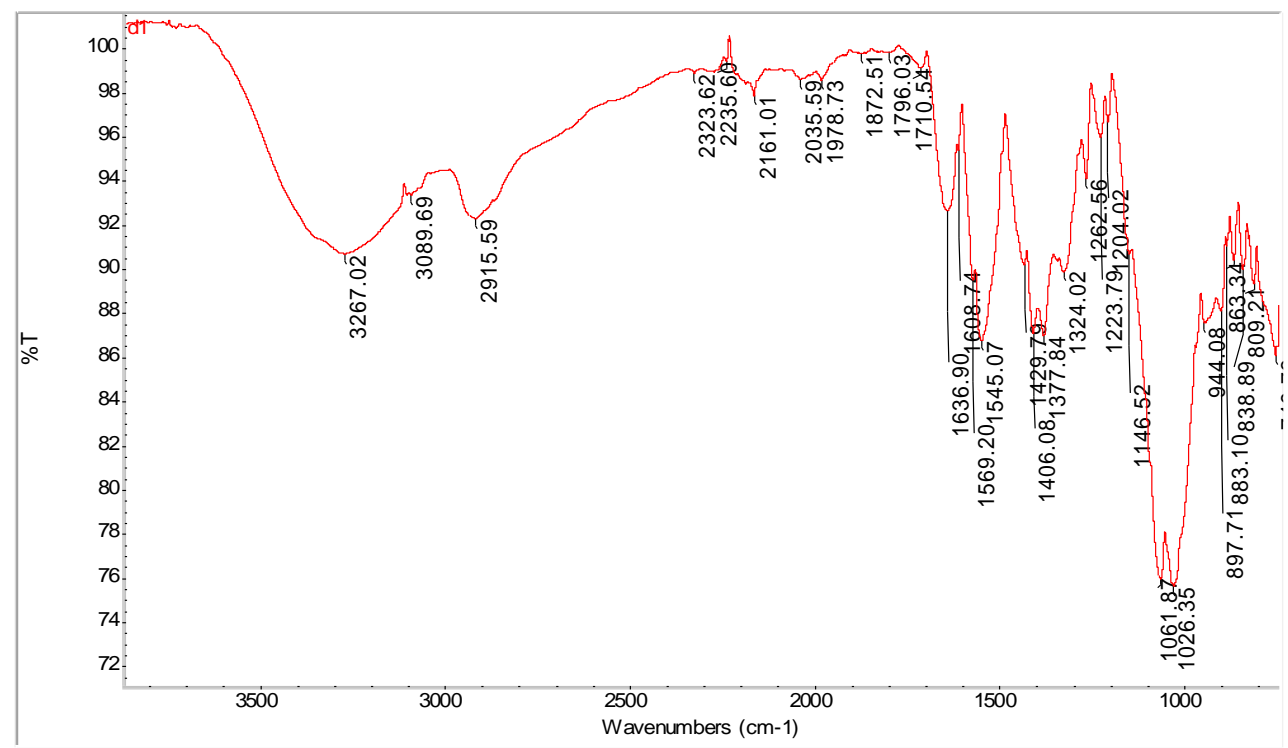

Figure 5: FTIR spectrum of CS NP with the characteristic signs.

\section{CONCLUSION}

In current study, CS NPs were prepared and characterization studies were performed. In these studies, particle size and charge, morphological properties, and FTIR results of NPs were evaluated. In conclusion, it can be concluded that CS NPs especially A3 and A4 formulations were suitable for use as a drug delivery system, and 
continued studies should be designed to increase the efficiency of NPs.

\section{REFERENCES}

1. Fan W, Yan W, Xu Z. Formation mechanism of monodisperse, low molecular weight chitosan nanoparticles by ionic gelation technique. Colloids Surf B 2012; 90:21-7.

2. Lam TD, Hoang VD, Lien LN, Thinh NN, Dien PG. Synthesis and characterization of chitosan nanoparticles used as drug. J. Chemistry, 2006; 44:105-109.

3. Jing ZW, Jia YY, Wan N. Design and evaluation of novel $\mathrm{pH}$-sensitive ureido conjugated chitosan/TPP nanoparticles targeted to helicobacter pylori. Biomaterials 2016; 84:276-85.

4. Sun Y, Wan A. Preparation of nanoparticles composed of chitosan and its derivatives as delivery systems for macromolecules. J Appl Polym Sci 2007; 105:552-61.

5. Retamal Marin RR, Babick F, Hillemann L. Zeta potential measurements for non-spherical colloidal particles-practical issues of characterisation of interfacial properties of nanoparticles. Colloids Surf A 2017; 532:516-21.

6. Csaba N, KopingHoggard M, Alonso M J. Ionically cross-linked chitosan/ tripolyphosphate nanoparticles for oligonucleotide and plasmid DNA delivery. Int J Pharmaceutics, 2009; 382:0514.
7. Koukaras KN, Papadimitriou SA, Bikiaris DN, Froudakis GE. Insight on the Formation of Chitosan Nanoparticles through Ionotropic Gelation with Tripolyphosphate Molecular J Pharmaceutics, 2012; 9:2856-2862.

8. Yang W, Fu J, Wang T, He N. Chitosan/sodium tripolyphosphate nanoparticles: preparation, characterization and application as drug carrier. J. Biomedical Nanotechnology, 2009; 5: 591-595.

9. Vino AB, Ramasamy P, Shanmugam V, Shanmugam A. Extraction, characterization and in vitro antioxidative potential of chitosan and sulfated chitosan from Cuttlebone of Sepia aculeata Orbigny, 1848. Asian. Pac. J. Trop. Biomed. 2012; 2: 334-S341.

10. Song $\mathrm{C}, \mathrm{Yu} \mathrm{H}$, Zhang M, Yang Y, Zhang G. Physicochemical properties and antioxidant activity of chitosan from the blowfly Chrysomya megacephala larvae. Int. J. Biol. Macromol. 2013; 60: 347-354.

11. Melo-Silveira, R.F.; Fidelis, G.P.; Costa, M.S.S.P.; Telles, C.B.S.; Dantas-Santos, N.; Elias, S.O.; Ribeiro, V.B.; Barth, A.L.; Macedo, A.J.; Leite, E.L.; et al. In Vitro Antioxidant, Anticoagulant and Antimicrobial Activity and in Inhibition of Cancer Cell Proliferation by Xylan Extracted from Corn Cobs. Int. J. Mol. Sci. 2012, 13, 409-426. 